\title{
Geological application of remote sensing (GARS), an IUGS/UNESCO joint program in the new millennium
}

\author{
Federal Institute for Geosciences and Natural Resources, Postfach 5101 53, D- 30631 Hannover, Germany
}

\begin{abstract}
IUGS and UNESCO founded the Geological Application of Remote Sensing Program (GARS-Program) during 1984 with the aim to assess the value of remotely sensed data for geological research and to enable institutes of developing countries to participate in the use of modern technology for their own research. Until now, the GARS-Program dealt in three phases with geologic and lithologic mapping in tropical environments of Africa, with landslide hazard mapping in the Andes mountain belt of South-America, and with volcanic hazard mitigation in The Philippines. Now, the GARS-Program embarks on a wider scope to contribute to the application of new remote sensing techniques as hyperspectral scanning, radar data interpretation and digital terrain modelling besides the more traditionals applications. New fields will be structural geology and hydrogeological investigations, geo-hazard mitigation, and geo-environmental studies. The overall goal will be the dissemination of the different experiences gained during the GARS-Program to those institutes that are interested to apply more effectively remote sensing methods.
\end{abstract}

Resources of arable land, water, groundwater and forests, and the expanding of human habitat are under increasing pressure almost worldwide. The non-industrialised countries, especially with their rapidly increasing populations, are facing severe problems from natural disasters, such as landslides, volcanic eruptions, earthquakes, soil degradation, water shortages and flooding. Geoenvironmental research can help to identify the causes of these events, point the way to rehabilitation measures, and lend support for early warning systems. Remote sensing adds considerably to this research by providing a wide variety of sensors operated from airborne and satellite platforms. Analysis of the data from these sensors can provide completely new insights into areas threatened by natural hazards. The GARS Program of UNESCO and IUGS provides a means of continually investigating the geological applicability of remote-sensing techniques. Their potential for assessing geoenvironmental conditions under various geological, climatic and morphological conditions are especially stressed.

Geologists were the first to benefit from aerial reconnaissance flights, back in the late 1920s and 1930s. The opportunity to raise the field geologist's view from the ground to the air gave his ground observations a new dimension. The next milestone in aerial reconnaissance was the elevation of aerial observation to altitudes of dozens of kilometres by the post-World War II rocket launches in the southwestern USA. These laid the foundations on which scien- tists from USGS (United States Geological Survey) and NASA (National Aeronautics and Space Administration) could begin to develop what is known today as remote sensing technology. The battle to have astronauts of the Gemini and Apollo missions take photographic cameras on-board their narrow space capsules during the early 1960s was described to me by Paul Lowman as extremely difficult, long, and full of setbacks. But once completed successfully, the NASA Earth Observations Program provided the earth sciences community with a vast number of breath-taking, spectacular and highly inspiring views of the Earth. It was the birth of geoscientific satellite remote sensing.

The multispectral scanner images from the first non-meteorological, civilian Earth observation satellites, the US LANDSAT series launched in 1972, surpassed the quality of the Gemini and Apollo photographs, which were taken mostly using hand-held cameras. The outstanding LANDSAT satellite program still exists (LANDSAT-7 was launched in April 1999), providing an evergrowing community of earth scientists with a continuous flow of Earth observation data. Other nations followed the LANDSAT program with programs of their own. Russia, France, Japan and India operate commercial earth observation satellites. Other countries will certainly follow suit. New sensors, notably in the microwave region of the electromagnetic spectrum, are operational. The Russian ALMAZ and RESURS programs, the European ERS program and the Canadian RADARSAT are examples.

The LANDSAT images were received enthusiastically by a small scientific community, mostly geologists, oceanographers and geographers. The proliferation went at a moderate pace compared to the broad acceptance satellite remote sensing data finds today. For the overwhelming majority of earth scientists, space observations from a distance of $900 \mathrm{~km}$ could not be of any significance at all. Most geologists flatly refused to admit that there could be anything geological worth mentioning in images of a 1:1 million scale. The use of a hammer and hand-lens and a topographical map was the state-of-the-art of data acquisition. Twelve years after LANDSAT-1 was launched, geologists convinced of the usefulness of Earth observation satellite data began to make themselves heard. The GARS Program, jointly sponsored by UNESCO and IUGS, was inaugurated in 1984 (Weber, 1985) at the same time as LANDSAT-4, containing Thematic Mapper, was launched, adding an additional three bands in the SWIR (short-wave infrared) to the existing visible (VIS) and near-infrared (NIR) bands. These new bands gave geological research a new dimension.

The objective of the GARS Program was to develop new methods for the integration of multisensor data in order to improve the mapping of lithological units, alteration zones, structural geology and mineralization in the Kibaran fold belt of Burundi and the Ubendian fold belt of Tanzania (Missotten \& Weber, 1988; Gabert, 1989). Five research institutions in Europe, the Geological Surveys of Burundi and Tanzania, and the Geological Departments of the universities of Dar es Salaam and Bujumbura were involved.

A result of this Phase I of GARS is the understanding that satellite imagery, besides providing new structural and lithological infor- 
mation, provides a data base of multi-thematic information (Chorowicz et al., 1990).

The planning of Phase II of GARS began in 1986, with the objective of mapping landslide hazards in the Andes using remote sensing and geographical information system (GIS) technology. A test site was chosen in Colombia, and geoscientists from Latin America, Canada, France and The Netherlands began their work in 1987. ESA (European Space Agency) and NASDA of Japan donated radar data and SPOT stereo data, and CNES (Centre National des Étude Spatial) and BRGM (Bureau des Récherches Géologique et Minières) provided financial support. Colombian scientists were involved in advanced training programs, including research work leading to a Ph.D. (Vargas, 1991; Chorowicz J. et al., 1998).

The emphasis of the GARS Program shifted towards the use of stereo models generated from satellite data, in this case SPOT image data and JERS-1 RADAR data in combination with data on slope angle, exposure to rainfall, geology, drainage patterns, land use, landslides, etc. The models were used to develop landslide susceptibility maps by entering all information into a geological information system (GIS) (Leroi et al. 1992).

European Community funding helped to produce the digital training package GISSIZ (Geographical Information System for Slope Instability Zonation) developed by ITC (International Institute for Aerospace Survey and Earth Sciences) (van Weesten, 1993). The GISSIZ is now used for training specialists from Latin American countries and Nepal. It is planned to extend these training workshops to other mountainous countries. Other institutions and research groups are invited to indicate their interest in a training course to ITC or the GARS Program.

Phase III of GARS commenced in 1993, to demonstrate the use of remote sensing, SAR in particular, for the analysis of volcanic and associated hazards in the Philippines.

Research has been carried out by PHIVOLCS (Philippine Institute for Volcanology and Seismology) in co-operation with the University of Paris VI in France, the Royal Museum for Central Africa in Tervuuren, Belgium, and the ITC in Enschede, The Netherlands. Mr. Robert Missotten, Secretary of the GARS Program, has been selected as Principal Investigator for the RADARSAT ADRO Program (Project ID No. 667). ESA provided ERS data, and NASDA provided JERS-1 radar data free of charge to the project to be used by different laboratories.

This, in brief, is the history of the GARS Program. Applications of remote sensing for geoscientific purposes are changing at an everfaster pace.

A tremendous wealth of scientific data has been generated since the 1960s and 1970s. This has led to a better understanding of the physical properties of multispectral signals of the VIS/NIR, SWIR, and TIR (thermal infrared) bands in the electromagnetic spectrum, the phenomena observed in microwave images, etc. At the same time, it has become obvious that images and data taken from space platforms provide synoptic views over large areas, leading to a much better understanding of geodynamic processes.

Today, with each new satellite in space, some of the previous work has to be repeated in order to test the new technologies. This has led to a wider acceptance of remote sensing for geological applications and it has found its place among the disciplines of the earth sciences. In numerous symposia world-wide, special sessions are dedicated to the application of remote sensing. At the IUGS 31st International Geological Congress in Rio de Janeiro, Brazil, five GARS symposia will be held that deal with remote sensing applications, and more than 20 symposia will be held on applications in which remote sensing is expected to play a major role as a tool.

Remote sensing has become a widely accepted research tool by almost all geological surveys the world over. Moreover, national and international geoscientific societies are promoting their specific applications of remote sensing. This development is encouraging. National and international organisations have included remote sensing research in their programs. Projects of various industries and the national space organisations can be added to these activities.
Naturally there are some shortcomings in this development. In particular, there are three persistent problems:

- In many research organisations in the industrialised countries remote sensing technologies are not used because their benefits are underestimated and therefore take a back seat to other research directions.

- Geoscientific organisations in developing countries still have problems in adopting remote sensing technology in their normal work and research programs. The high cost of remote sensing data, computers and software, rapidly changing technical development, and lack of adequate training for staff hamper wider application in these organisations.

- Coordination between users and providers of remote sensing technologies in many cases leaves much to be desired. To justify a satellite project, anything from benefit to developing countries to prevention of specific natural disasters will be cited. Profit-driven, dedicated satellites for observations of the Earth are few, and usually sponsored by organisations outside the national space agencies. They act quickly, but not always successfully. Programs for dedicated satellites find it difficult to obtain funding. Space data are saleable. But non-profit data users, even for humanitarian early warning programs, do not seem to find the necessary support.

In view of this situation, it is recommended that the future direction of the GARS Program should be discussed. There is a obvious need for a geological applications clearing house, encouraging dialogue between users and potential users. The user community's voice would be heard more clearly by the data providers and the builders and operators of remote-sensing instruments if the user community could speak in a more coordinated way.

UNESCO views the GARS Program as a tool for promoting international scientific exchanges, especially between experienced institutions and less-experienced ones. IUGS regards the GARS Program as an entity to test the usefulness of the various types of remote sensing data for geoscientific purposes. The participating institutions profit from the scientific exchanges, as well as the opportunity for international cooperation. It very often enables them to obtain future funds from their supporting agencies.

The GARS Program is currently enlarging its scope in order to adapt to the present situation. Cooperating institutes will include those with long experience in the use of various sensors and methods for different geological applications. This has already led to increased competence within the cooperating agencies in the developing countries, as well as in the more experienced institutes.

The scope of the GARS Program will be expanded towards geoenvironmental assessment. The Program will continue:

- to develop and demonstrate the use of advanced remote sensing techniques for solving key geological problems,

- to ensure the transfer of information and technology through cooperative field research and educational outreach, and

- to ensure wide dissemination of its findings.

Future research programs will include the following topics:

- volcanic hazard assessment,

- neo-tectonics, especially active faulting,

- landslide hazard assessment,

- hydrogeology in arid and semi-arid countries;

and geological application of

- signatures in radar images and their interpretation,

- radar interferometry,

- digital terrain modelling,

- laser scan methods, and

- hyperspectral methods.

It is desired to expand the number of cooperating institutions in the GARS Program in order to create a network in which application-oriented geological research and discussion between experienced institutions and less-experienced institutions can help to narrow the still-existing gaps in knowledge and experience. 
Interested institutes are encouraged to contact the GARS Program via the addresses as follows.

\section{Chairman:}

Dietrich Bannert

Federal Institute for Geosciences and Natural Resources

Postfach 510153, 30631 Hannover, GERMANY

Tel: +49 $511643-0$

Fax: +495116432 304

E-mail: dietrich.bannert@bgr.de

\section{Secretary:}

Robert Missotten

UNESCO - Division of Earth Sciences

7, place de Fontenoy, 75700 Paris, FRANCE

Tel: +33145684117

Fax: +33145685822

E-mail: r.missotten@unesco.org

\section{References}

Chorowicz, J., Lavreau, J., Tamain, G., Theunissen, K., Bardinet, C., Girault, F., Klerkx, J., Lepage, A., Nanyaro, J., Ntungicimpaye, A., Roggeri, I., Rudant, J.P., Ruder, J., Tack., Temu, E., Thouin, C., Tréfois, P., and Yand, P., 1990, The use of satellite imagery for the study of the lithology and the ancient and reactivation tectonics in the vicinity of the East African Rift: ISPRS Journal of Photogrammetry and Remote Sensing, $45,355-381$.

Chorowicz, J., Scanvic, J -Y., Rouzeau, O., and Vargas Cuervo, G., 1998, Observation of recent and active landslides from SAR ERS- 1 and JERS1 imagery using a stereo-simulation approach: Int. J. Remote Sensing, 19, $16,3187-3196$.

Daag, A. and van Westen, C., 1996, Cartographic modelling of erosion in pyroclasic flow deposits of Mount Pinatubo, Philippines: ITC Journal 1996-2, 110.124 -Enschede.

Gabert, G., 1989, The GARS Kibaran Project in Africa: Episodes, 95-96.

Guillande, R., Caro P., and Chorowicz J., 1991, A first approach to digital mapping of landslide hazards in the Andes of Colombia using remote sensing techniques (GARS project): Episodes, vol. 14, 364-367.

IUGS, Minutes of the 44th Executive Committee Meeting, January 26-30, 1998.

Leroi, E., Rouzeau, O., Scanvic, J-Y., Weber, C.C., and Vargas, C., 1992, Remote sensing and GIS technology in landslide hazard mapping in the Colombian Andes: Episodes, vol. 15, 32-35.

Leroi, E., Missotten, R.., Rouzeau, O., Scanvic, J-Y., Vargas, C., and Weber, C.C., 1995, Methodology for Regional Mapping of Natural Hazards using Remote Sensing and Geographical Information Systems. The expe- rience of the GARS programme in Colombia: Geol. Survey of Japan Report, No. 281, 101-108.

Missotten, R. and Weber, C., 1988, The objectives of the GARS Program: Mus. Roy. Afr. Centr., Tervuuren (Belg.), Ann. Série in-8é, Sc. Géol., 96, $1-3$.

Naranjo, J. L., van Westen, C., and Soeters, R., 1994, Evaluating the use of training areas in bivariate statistical landslide hazard analysis - a case study in Colombia: ITC Journal, 1994-3, 292-300 -Enschede.

Van Westen, C. J., 1993, GISSIZ - Training Package for Geographic Information Systems in Slope Instability Zonation: ITC publication Nr. 15, 2 vol., Enschede.

Van Westen, C.J., Soeters, R., and Rengers, N., 1994, GISSIZ: Training Package for Geographic Information Systems in Slope Instability Zonation: Proceedings of the ERIM Tenth Conference on Geologic Remote Sensing, San Antonio, TX, 9-12 May 1994.

Van Westen, C.J. and Terlien, M.T.J., 1996, An approach towards deterministic landslide hazard analysis in GIS, a case study from Manizales (Colombia): Earth Surface Processes and Landforms, Vol. 21, 853-868 John Wiley, London.

Vargas, G., 1991, Méthodologie por l'établissement des cartes des senibilité aux mouvements de terrain fonde l'utilisation d'un couple stéreographique Spot TM, Applications de la région de Paz del Rio, Colombie: Mémoire de DESS, Universit Pierre et narie Curie, Paris VI (Francee, juillet 1991.

Weber, Ch., 1985, Geological remote sensing: Quo vadis?: ITC Journal, $1985,4,227-241,12$ figs.

Dietrich Bannert is chairman of the UNESCO/IUGS GARS Program and Director of the Remote Sensing Section of Federal Institute for Geosciences and Natural Resources in Hannover, Germany. He earned his doctorate in 1964 from the Philipps-University in Marburg, Germany. During 19691970 he stayed at NASA Manned Spacecraft Center in Houston, USA, where he proved the usefulness of orbital photography for geological investigations. He worked in Middle East, Africa, Asia and Latin America. His main fields are applications of remote sensing to hydrocarbon prospecting, mineral prospecting, hydrogeology, structural geology and environmental geology.

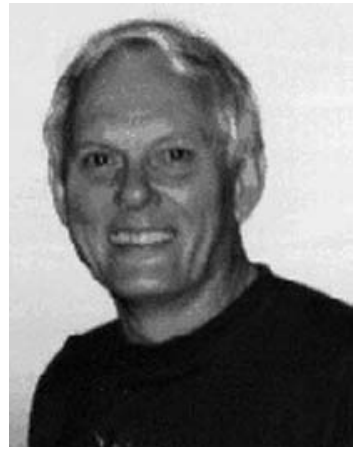

\section{CALL FOR PAPERS}

Episodes is the quarterly science and news journal of the International Union of Geological Sciences (IUGS). It focuses on the publication of results of scientific research and other information addressing issues of interest to the global earth-science community. Special emphasis is given to topics involving geological aspects of population growth and economic development and their resulting impacts on or implications for society. As the principal publication of the IUGS, Episodes also carries information about IUGS scientific programs and activities to the extent necessary to communicate effectively with the worldwide IUGS constituency.

Contributions of the following types of manuscripts are here solicited:

- scientific articles

- review papers

- conference reports

- news and views

- letters to editor

- book reviews

- information on training courses (especially those geared to participants from developing countries)

- noteworthy new publications, including national or regional geologic maps

Please address all contributions to: The Editor

Episodes

P. O. Box 823, 26 Baiwanzhuang Road, 100037 Beijing, CHINA

Tel: +86-10-68320827; Fax: +86-10-68328928;

E-mail: episodes@public2.bta.net.cn 